\title{
'Hallo hoe gaan dit, wat maak jy?': Phatic communication, the mobile phone and coping strategies in a South African context
}

\author{
Fie Velghe \\ Tilburg University
}

\begin{abstract}
This paper looks at the ways in which the mobile phone has become a means through which phatic communication is being expressed. More specifically, the paper shows how, in an impoverished community such as the Wesbank township in South Africa, phatic communication and 'maintaining a connected presence' are vital strategies of social networking. In a context of severe and desperate impoverishment, loneliness, chronic unemployment and boredom, the exchange of phatic communicational gestures such as a text message or a short phone call forms one of the many coping strategies that the residents in Wesbank employ to face up to the harsh conditions of poverty and insecurity.
\end{abstract}

Keywords: mobile phones; phatic communication; conviviality; voice; South Africa

\section{INTRODUCTION}

Tmagine walking down the road in 1 your neighbourhood and the old lady living on your street-who usually greets you when you walk by-is suddenly not answering your friendly greeting anymore. Or your neighbour, with whom you normally exchange some friendly, formalised 'small talk' such as 'Hello, how are you?' and 'What bad weather we have today!', is ignoring your routine attempts at interaction. Imagine sending a text message to a friend you have not heard from for a long time, just to say you are thinking of him and that you hope that everything is alright, but not getting a text message or a call back; or posting a (in your opinion quite funny) status update on your Facebook wall and none of your 300 Facebook friends 'likes' it. Or, finally, imagine a friend of yours, who usually posts a huge (and in your view sometimes irritating) number of tweets daily on his Twitter account, suddenly not tweeting at all.

All the above-mentioned situations would probably make you feel uncomfortable and make you wonder: Did I do something wrong? Have I done something to upset my neighbour or the old lady in my street? Is my friend angry with me for some reason? Was my Facebook post maybe not so funny 
after all? Is my silent Twitter friend ok? It is only when such daily, routine social interactions cease to take place that we realize their actual importance. When they disappear, we are suddenly left with a feeling of worry or of being unheard and unappreciated. We may think of the other person who infringes the reciprocity of such social interactions as impolite, rude, pretentious or egocentric. This is because such communicational exchanges that do not necessarily intend to inform or exchange any meaningful information do have another, no less important purpose: a social one (Malinowski 1923). With such 'phatic communication', one aims to express some kind of sociability and to maintain social connections and bonds (Miller 2008). Even though you know nothing about that old lady living in your street, and apart from 'Hello, how are you?' you never really entered into a conversation with her, those simple greetings do give you the feeling of being connected with her in some way. Also, your friendly greetings to your neighbour have made it possible for you to go and ask him, without any feeling of guilt, if you can borrow his drill when you are doing some small jobs in the house. And, although you have not seen your friend for a very long time, an SMS every now and then does, however, give you the feeling of being in touch with him and being updated about his life.

This article looks at how the mobile phone has become a means through which such phatic communication is being expressed and how communications such as a text message, a short call, or a short comment on someone's Facebook wall 'becomes part of a mediated phatic sociability necessary to maintain a connected presence' (Miller 2008: 395). We will see how, in an impoverished community such as the Wesbank township in South Africa, phatic communication and 'maintaining a connected presence' are vital strategies of social networking. In a context of severe and desperate impoverishment, loneliness, chronic unemployment and boredom, the exchange of phatic communicational gestures forms one of the many coping strategies that the residents in Wesbank employ to face up to the harsh conditions of poverty and insecurity.

I will start by giving a brief description of the research site, Wesbank, and then turn to some examples of phatic communication and its socio-economic implications, followed by a review of other literature on phatic communication in relation to poverty and coping strategies.

\section{THE FIELD: WESBANK}

Wesbank community, which officially became a residential area in 1999, five years after the abolishment of apartheid, is by all accounts a peripheral township, characterized by poverty, unemployment and high crime rates (Blommaert et al. 2005). It is situated on the Cape Flats, the so-called 'dumping grounds of apartheid', a dry and sandy low-lying area 27 kilometres from the centre of Cape Town and surrounded by many other apartheid townships. The building of the township started in 1998 as part of the 'reconstruction and development programme' (RDP), a national socioeconomic policy framework which the first democratic government in South Africa implemented in 1994 to tackle the economic, racial and spatial legacies of apartheid and to improve government services and basic living conditions for the poor.

The building of Wesbank was one of the first post-apartheid housing projects in the area of Cape Town that was not segregated along racial lines, but was intended to provide housing for deprived 
people irrespective of colour and descent. 'Black', 'coloured' and some 'white' people, and a growing number of African immigrants, live in the same community, although $67 \%$ of the population is 'coloured' and Afrikaans-speaking (Dyers 2008; Census 2013). This first so-called 'rainbow community' gave a home to 25000 people in 5149 fully subsidized houses. The actual number of residents is estimated to be much higher, but recent statistics and numbers for the area are not available. All the 'RDP houses' in Wesbank have been granted for free to people who were eligible for a full subsidy house, targeting families with a monthly income of less than R3 500 (approximately €266). The low-cost houses have an average size of 25 square metres, are very poorly equipped and not isolated.

Poverty has been a characteristic feature of the population since the first days of Wesbank's existence. Wesbank has a very low average education rate, with only about $10 \%$ of the inhabitants having finished grade 11-12 (Blommaert et al. 2005). In ward 19, the administrative area that contains Wesbank, only 26.9\% of those aged 20 years or older have finished their last year of secondary school (Census 2013). As a consequence, many middle-aged residents are illiterate or sub-literate and unskilled, which makes it very hard for them to find a formal job. While recent unemployment rates for the Wesbank community are not available, the latest report on ward 19 as a whole gives an unemployment rate of $25.8 \%$ (Census 2013). The overall basic service delivery is also very limited. Gangsterism and crime rates are very high, mainly due to high unemployment rates, the constant inflow of new residents, easy access to drugs, alcohol and firearms, the absence of a police station in the area and the flourishing, deeply rooted presence of two big and many small criminal gangs.

\section{DATA COLLECTION AND METHODOLOGY}

This article draws on three extensive ethnographic fieldwork periods in the community of Wesbank between January 2011 and June 2013, with a total stay of 16 months. The study included in-depth, face-to-face interviews with 33 middleaged women and one group interview with eight women attending the senior craft club organized in Wesbank. The women interviewed face-to-face were all between 40 and 65 years old, with the exception of one 25-year-old woman. Face-to-face interviews were all held at the women's premises and lasted between one and two hours. Potential interviewees were selected and introduced with the help of two community workers or by snowball effect, in which interviewees introduced friends or neighbours. Although a list of questions was used as a reference, the interviews were semi-structured, allowing interruptions, follow-up questions and space and time for interviewees to accentuate their own fields of interest.

Other data were gathered by handing out two different questionnaires in the high school, one primary school and the multi-purpose centre in Wesbank. Six interviewees kept a mobile phone diary in a small notebook in which they noted all the text messages and phone calls they made and received during the course of one week. Three cell phone courses were organised in which I was assisted by two teenage girls who taught the participants how to send and read and reply to text messages and/or how to use the internet. In total I have assisted nine women with how to compose, send and answer text messages, six women with how to create 
and operate a Facebook and e-mail account, and two women with how to use Google and Wikipedia. All these women have also been interviewed and closely followed up afterwards; I paid them regular visits during which they could ask questions, repeat things learned and during which I could collect a corpus of text messages, screen shots and get a clear view on their learning processes and vulnerabilities.

As much time as possible was spent in the community and daily observations of interactions, literacy classes for adults, social gatherings, family situations, mobile phone use, and informal conversations were written down in a fieldwork diary, following participant observation. Other data included pictures, text messages received and sent, screenshots of Facebook, WhatsApp and MXit conversations, etc. (see Velghe 2014 for a more detailed description).

\section{4. 'PHATIC' \\ COMMUNICATION IN A NEW COMMUNICATIVE ENVIRONMENT}

Malinowski (1923) was the first to use the term 'phatic exchange' in 'describing a communicative gesture that does not inform or exchange any meaningful information or facts about the world' (Miller 2008: 393), referring to verbal exchanges that primarily serve a social purpose, to express sociability and maintain connections or bonds. Such phatic messages are not intended to carry information or substance to the receiver, but instead concern the process of communication (Miller 2008). According to Vetere et al. (2005), 'phatic acts ensure existing communication channels are kept open and usable'. Phatic communication thus leaves the door ajar, so to speak, for further communication, sociability and, as we will see below, survival or coping strategies in a context of severe poverty.

As suggested above, we may think of a person who infringes the reciprocity of a friendly greeting as being impolite, rude, pretentious or even egocentric. We may also, when the person in question is mentioned in a conversation, make comments such as "This guy suddenly thinks he is too good for me' or 'She is so pretentious'. Leaving out 'phatic' gestures in the meeting and greeting of other people can clearly impinge on our feeling of 'conviviality' (Blommaert 2012). According to Blommaert (2012: 10), 'people perform low-intensity and apparently low-salience forms of interaction tailored towards a sense of commonness' that leads to conviviality. For instance, the many Congolese, Somalian, Nigerian, and Zimbabwean refugees who live in Wesbank and own informal shops and businesses are all very proud of being capable of exchanging greetings with their clients in Afrikaans or isiXhosa, the two main languages spoken in the community. Although expressions such as 'hallo, hoe gaan dit' (Afrikaans for 'hello how are you') or 'molo, unjani' (isiXhosa for 'hello how are you') do not carry substantial information to the receiver and instead mainly concern the process of communication, they do have the capacity of strengthening existing relationships in order to facilitate further communication (Vetere et al. 2005, cited in Miller 2008: 394) and to sustain a feeling of conviviality and sociability. According to Miller (2008: 395), 'one should not assume that these phatic communications are "meaningless", in fact, in many ways they are meaningful and imply recognition, intimacy, and sociability in which a strong sense of community is founded'. 
Miller (2008: 387) stated that phatic communication'hasbecomeanincreasingly significant part of digital media culture alongside the rise of online networking practices'. Through the emergence and high uptake of new information and communication technologies (ICTs) we now have a multitude of channels and devices on which 'small talk' and phatic gestures can take place. In what Miller (2008) calls the 'phatic media culture', we tend to constantly 'keep in touch' in order to 'maintain a connected presence in an ever-expanding social network' (Miller 2008: 395). We can chat, skype, tweet, email, 'poke', 'like', SMS, call, etc., in our attempts to connect with others without being physically present.

According to Lacohée et al. (2003: 206), the mobile phone facilitates communication as 'the perfect tool for increased levels of social grooming, i.e. letting someone know that you are thinking about them': text messages can be very low in information but high in 'social grooming'. In their research on mobile phone use and SMS texting amongst Australian youngsters, Horstmanshof and Power (2005) found that text messaging is primarily used for making connections, affirming relationships and friendship maintenance, fulfilling phatic and social-relational functions. Since phatic interactions create expectations of reciprocation, Horstmanshof and Power (2005) are of the opinion that youngsters are able to find help with boredom and anxiety by reaching out to their friends with text messages in the confident belief that at least one of their friends will respond. As we will see below, middleaged women in Wesbank also seek recourse on their phones when boredom, insecurity, or a feeling of depression hits them. Also here, (SMS) messages are not necessarily used to exchange 'content', but more for the creation of a sense of being in social (phatic) contact with others
(Horstmanshof et al. 2005). Similarly to what Miller and Horst (2006) found in their research, in Wesbank making short and frequent phone calls is another way in which the mobile phone lends itself perfectly as an instrument for phatic interaction: such calls maintain and strengthen 'presence' in which the act of calling counts more than what exactly is being said (Licoppe 2004). This is what Horst and Miller (2006) call 'link-up' in their anthropological study on mobile phone use amongst low-income families in Jamaica. In a similar vein, Miller (2008) states the following:

we see a shift from dialogue and communication between actors in a network, where the point of the network was to facilitate an exchange of substantive content, to a situation where the maintenance of a network itself has become the primary focus. Here communication has been subordinated to the role of the simple maintenance of ever expanding networks and the notion of a connected presence. (Miller 2008: 398)

As we will see in the next section, in Wesbank, it is exactly the maintenance of networks and social bonds that seems to be the primary focus of a lot of online, offline and face-to-face communication. In a context of severe poverty, the employment of phatic gestures-part and parcel of daily encounters and communicational exchanges-is one of the many coping strategies that the residents of the impoverished community employ in order to deal with the harsh conditions of living their lives in poverty and insecurity. The mobile phone has given the residents a new medium through which they can now maintain, strengthen and extend their relationships and networks with people both from within and outside the community. 


\section{PHATIC \\ COMMUNICATION AS A SURVIVAL STRATEGY}

As mentioned above, the kinds of communicational exchanges that do not necessarily intend to inform or exchange any meaningful information do have another, no less important function: a social one (Malinowski 1923). Greeting the old lady in the street, I did not have the intention to stop and engage in lengthy conversations with her about her private life, politics, or the financial crisis. I greet her because we are both human, because saying hello 'does not cost a thing', because it creates a sense of conviviality, and because I do not want to appear as an unfriendly and rude person to her. For the same reasons I say 'assalamu aleikum' to the Pakistani shopkeeper in my neighbourhood, with whom I also do not have the intentionlet alone the capacity - to engage in further conversations in Urdu or Pashto; yet, my greeting in 'his' language creates a kind of sociability and commonness that is always clearly appreciated.

Although people who disregard (the reciprocity of) phatic gestures can be quickly labelled as rude, impolite, pretentious or egocentric, not respecting or failing to engage in phatic exchanges would not necessarily influence our lives in disastrous and life-threatening ways. Had I not greeted my neighbour consistently from our first encounter onwards, he probably would have refused to lend me his drill when I asked for it, or perhaps I would not have asked him to lend me his drill in the first place, since I would not have had the feeling that my level of connection with him lends itself to a request like that. This, however, would hardly have made my life unbearable.
Similarly, greeting the Pakistani shop owner in my neighbourhood with an assalamu alaikum has maybe incited him to sometimes offer me a free loaf of bread, but had I not done that, or greeted him at all, I would still be able to go and shop in his store.

In contrast, for people who live their lives on a shoestring budget, phatic communication can be of vital importance. As mentioned, phatic communication leaves the door ajar, not only for further conversation and sociability, but also for survival and coping strategies. According to Horst and Miller (2006), the primary source of survival amongst low-income populations consists of other people and social networks. Based on their research in Jamaica, they suggested that the mobile phone should, therefore, not be seen as a mere addition to the household or as a luxury item, but 'as something that dramatically changes the fundamental conditions for survival of low-income Jamaicans, because it is the instrument of their single most important means of survival-communication with other people (Horst and Miller 2006: 57). Social connectedness and connected presence have the possibility of generating a safety network of acquaintances, neighbours, church members, friends, family members, colleagues, old school mates, etc. that can be counted and called upon when help, counselling or advice is needed.

In what follows, we will look at examples of how three Wesbank residents employ phatic gestures on their mobile phones in order to create a connected presence that can help them to cope with the harsh realities of poverty, unemployment and boredom.

\section{Lisa}

Lisa is a 45-year-old Wesbank resident and single parent of three children, of 
whom only the youngest, her 13-year-old daughter, still lives with her. Originally from Oudtshoorn, more than $400 \mathrm{~km}$ away from Cape Town where most of her brothers and sisters still live, Lisa has been living in Wesbank since the first days of its existence. As a single mother with no regular income, Lisa applied for a full-subsidy house in Wesbank. Between 1999 and 2010, she was able to survive and take care of her family without having a formal, fixed job. Throughout the years, Lisa has established several informal businesses in order to gain just enough money to support her family. She has been buying meat and other groceries in bulk to then sell them with a little bit of profit to other residents; she has made and sold craftwork, and she also participated in a sort of 'saving group' of women who collectively contributed a certain amount of money to a central fund, a stokvel. Each month, a different member of the group received the stokvel, giving the members the opportunity to buy groceries in bulk, to cover unexpected household costs, or to invest the money. Lisa has also been buying 'food stamps' at Shoprite, one of the biggest supermarkets in South Africa, to then sell them in the community.

However, above all she has been able to survive since she has always been loved and known by many people in the community and, as a member of the New-Born Christians, has also become known as a very devoted Christian, attending church meetings and Bible study several times a week. For as long as I have known her (since 2005) she has always had neighbours and other community members popping in and greeting her on the street and she has always been willing to help-financially, emotionally, or practically-others in the community.
The case of Lisa resembles what Horst and Miller found in their research on Jamaican low-income households: they see networking as vital in understanding coping strategies, but according to them the implications of cause and effect could also be reversed-people give and take not because they need to do so but also in order to facilitate connectedness (Horst and Miller 2006). Lisa's generosity and friendliness made her connected to a lot of residents of Wesbank who all, in turn, have become part of her safety network.

Instigated by her daughter, Lisa started chatting on the very popular South African mobile instant messaging programme MXit. Very swiftly, Lisa became a fervent and daily MXit chatter using the nickname 'Sexy Chick'; chatting in chat rooms and on a one-to-one basis mainly with men she had 'met' on MXit. She started to live a 'loose' sexual life-both virtually as well as offline-by flirting with different men from outside the community and even outside Cape Town, regularly also meeting up with them. The first offline encounter always took place outside the community and for subsequent encounters they either met in a pub, in a hotel, or, when she trusted the man well enough, in her house. MXit had opened a whole new world for Lisa; the adoption of a mobile phone and her phatic chat sessions with unknown men on MXit had made it possible for her to transgress her own immediate lifeworld and both mentally and physically leave the seclusion of her house and the community. The men she has met have taken her out for dinners, have paid for a night in a hotel, and given her presents and money, etc. Next to tangible things, the chats on MXit have given her the feeling of 'being out there' and the possibility to expand her networks and broaden her safety net. 
Lisa also used MXit to chat with her son-a soldier based in a province on the other side of the country-and other family members and friends. Figures 1, 2 and 3 below are examples of how Lisa used her mobile phone (MXit and text messaging) to stay in touch with me by the mere exchange of phatic gestures.

Figure 2 is a text message Lisa sent to me when I already had finished my fieldwork stay and had left South
Africa for Belgium. The mobile network operator that Lisa was using charged 1.75 ZAR per international SMS, which is more than double the cost of a national SMS and five times more expensive than a national SMS during off-peak hours. Given that people in Wesbank, on average, buy airtime vouchers of R5, a text message of R1.75 is a considerable amount. Moreover, the text message Lisa sent to me was so short that it only used

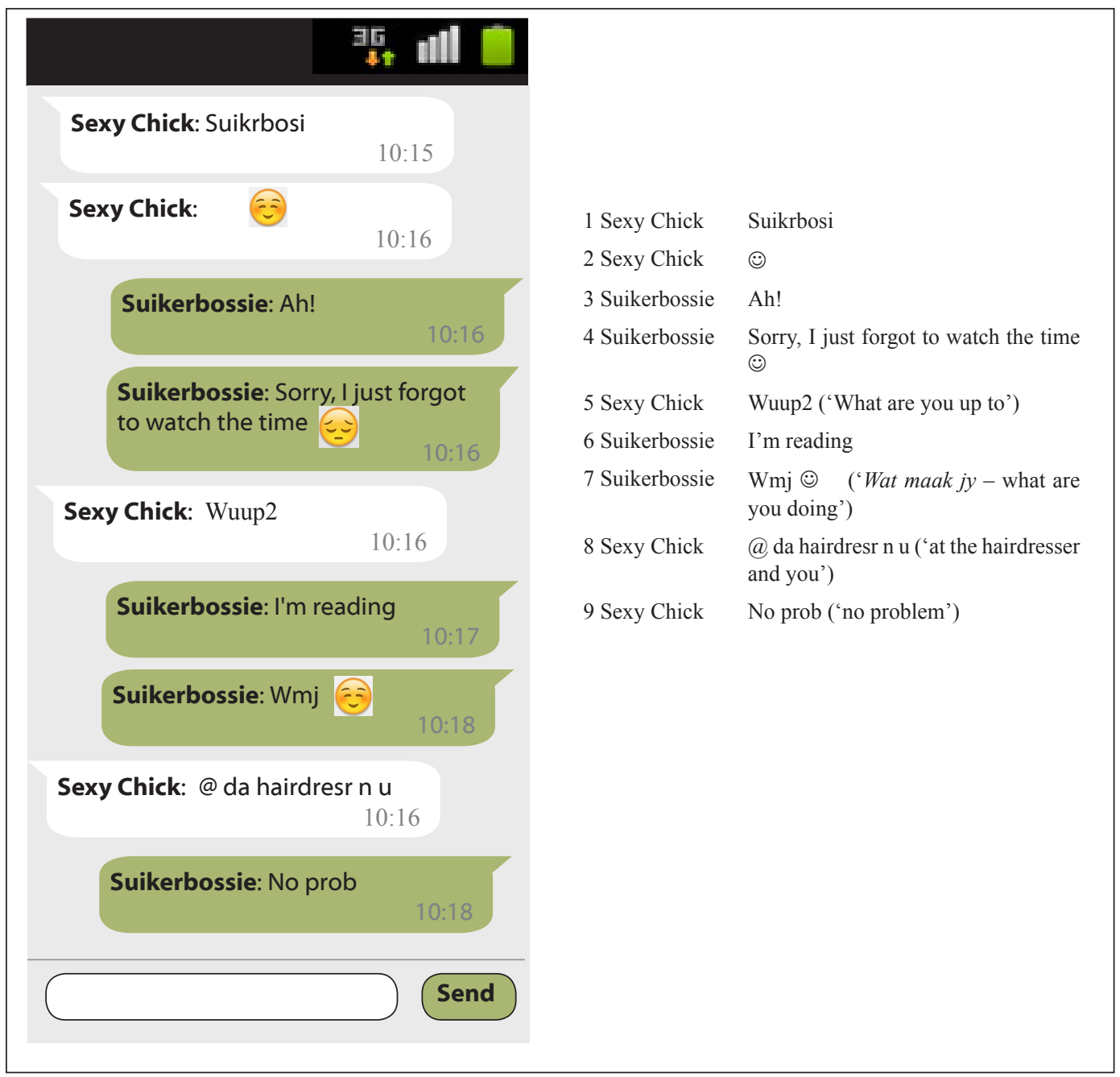

Figure 1: Phatic exchanges between 'Sexy Chick' and the author (Suikerbossie) on MXit (2011) 
Dis 'kak' koud hier by ons. Mwah

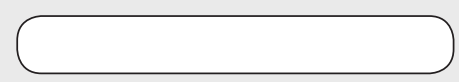

Send
'It's 'shitty' cold here our side. Mwah' [onomatopoeic sound for a kiss]

Figure 2: International phatic text message from Lisa to the author (2012)

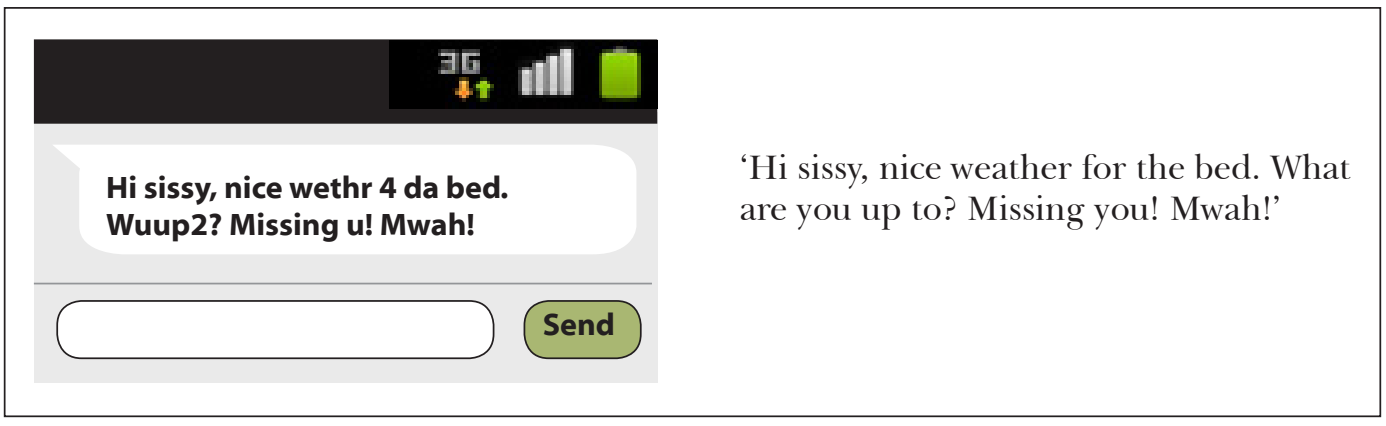

Figure 3: Phatic text message from Lisa to the author (2012)

32 of the total of 160 characters available in an SMS. The moment I received the SMS I was in no doubt why Lisa would spend so much money on a text message just to tell me that it was very cold in Cape Town. This seemingly 'meaningless' SMS made me smile, made me realize she was thinking of me, and prompted me to take my phone and call her, thus strengthening our bonds although we were thousands of miles apart.

In 2012, Lisa suddenly had a boyfriend whom she had met in Wesbank through mutual friends. Since he did not really have a place to stay-he was sleeping on a mattress in the shop he owned-he had moved in with her at quite an early stage of the relationship. The relationship had its ups and downs, predominantly because of the boyfriend's extreme jealousy. After moving in, he had immediately forced her to stop chatting on MXit since 'she did not need it anymore'. Every couple of weeks, they had huge conflicts and discussions about all the men and women popping in her house without a 'real' reason, about Lisa greeting men in the street, doing favours for others, or visiting and spending time with neighbours and other acquaintances in the community, again, according to him, 'without real purpose'. Lisa desperately, though unsuccessfully, tried to explain to her boyfriend that those encounters and chats were important to her, since it was those very interactions that had helped her survive throughout the years. Her boyfriend regarded the phatic exchanges as being 'superfluous' and 'too much', and could not understand that Lisa needed those interactions in order to live a comfortable and happy 
life. She mentioned to me several times that she was afraid that her boyfriend would force her to renounce her contacts and networks in the community and thus lose her safety network. Lisa realized well enough that she had always been able to survive in the community by pursuing conviviality and by respecting the importance of phatic gestures and phatic communicational exchanges. She told me that she was worried about the fact that, if she and her boyfriend would ever break up, she would be left alone without a safety network to call or count upon.

\section{Katriena}

Katriena grew up on a farm in the countryside. Being the oldest child, she never had the chance to go to school as she had to look after her siblings while her parents were working on the farm. At the age of 16, only capable of writing her name and surname, she had tried to learn how to read and write by herself, copying words she saw around her and trying to decode words and sentences from newspapers and magazines. It was only at the age of 62 , when she had started following adult literacy classes in Wesbank, that she attended school for the first time. Very laboriously, she was now capable of reading the Bible and occasionally read magazines and spiritual books. Katriena had had a mobile phone for a couple of years, but had only been able to use the handset to answer and make calls and to send off 'Please call me' (PCM) messages ${ }^{1}$. After following two cell phone courses I organised as part of my fieldwork, Katriena had started using this Short Message Service extensively. I had asked Katriena to keep a cell phone diary of her activities and in the six days following the cell phone courses, she sent 39 text messages, an average of 6.5 messages a day. This is a lot, especially if we look at her cell phone diary for the two months before the courses-during the course of one week, zero messages had been sent and seven received, of which four were advertisement messages from the cell phone carrier and two were PCM messages. Only one was an actual message she had received from a church member who wanted to find out whether Katriena was at home. Looking at the text messages that Katriena sent in the first week after the cell phone course, we see that the text messages were all very short and quite similar to one another (see figures 4-7 below). She started using this new communication channel mainly to greet the addressees and to be informed about their wellbeing, clearly with the intention to open up the new channel that the use of text messages had created for her and to show the addressees that she was 'out there', now using the new medium.

In other words, the text messages must be seen as 'mere' communicative gestures, expressing sociability and forging connections and networks through a newly discovered medium. Not so much the content, but the act of communication is important here. Katriena is an older lady in her sixties with severe medical problems and going out and walking around in her gang-controlled neighbourhood is a source of great anxiety for her. The use of text messages became the most convenient and safe way for her to stay in touch and link-up with friends, church members, family and even neighbours without having to leave her house.

It was only after some weeks of familiarisation that Katriena's text messages became longer and changed in content. She started using the SMSs to also exchange information, organise her life, manage her household and to ask for help when 


\section{䋕 inll D}

Ek is lief vir julle

'I love all of you'

Send

Figure 4: SMS from Katriena to a family member (2012)

\section{an till D}

Hai sis hoe gaan dit met u want ek stel nogbelang in u van sist

Katriena liefde.
'Hello sis how are you because I still care for you from sister Katriena love.'

Send

Figure 5: SMS from Katriena to a church member (2012)

\section{판, ㄴlll}

Die here is goet vir my ek hoop om die selfde van juo ti hoor

The lord is good to me I hope to hear the same from you'

Figure 6: SMS from Katriena to a friend in Wesbank (2012)

\section{파 toll D}

Halo muisie hoe gaandit met julle twee lieflinge van my hart dit is al waat ek wil weet suster
'Hello girl how are you two loved ones of my heart that's all I want to know sister'

Send

Figure 7: SMS from Katriena to her daughter (2012) 
needed. For instance, in figure 8, Katriena asks a friend in Wesbank if she could send her son to get her medicines.

All the text messages in which Katriena asked for help (to go and collect her medicines, to water her plants, to come and pick her up for the Sunday service at her church, etc.) were preceded by text messages to the same people with mere phatic content (see figure 9).

After first 'linking-up' by sending a phatic text message, Katriena probably thought she was now connected enough to appropriate the new medium for asking for help or favours. In the weeks after the cell phone course, I also received several text messages from Katrienasome to thank me for the lessons, others just to tell me that she had received my messages, that she was at home, or to tell me that she loved me. Suddenly
I also received a text message in which she asked me to lend her R20 for her electricity expenses. She had never asked me for such financial favours before, but apparently was of the opinion that our constant connectedness through SMSs had forged our relationship in such a way that it was now appropriate for her to do that. This presumption is in line with the findings of Horst and Miller (2006), who stated that a lot of mobile phone communication is carried out in the hope of continuously creating new possibilities through personal networking. According to them, the phone is not only used to search for employment or to carry out entrepreneurial work, but even more importantly as the possible creator of extensive networks and as the perfect medium to engage in a large number of small conversations with various

\section{판, till}

wat gaan an war om antwood jy my nie of het hy nie die pille ge gaan haal nie laat weet my ek is ge wharrie liefde
'What is happening why don't you answer me or did he not go and get the medicines let me know I am worried love'

Figure 8: SMS from Katriena to a friend in Wesbank (2012)

\section{画}

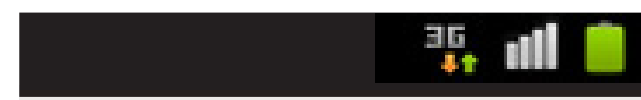

Halo ek vir lang na julle ek mis julle beai ek mis julle ek kan nie wag om huis toe te kom nie..

Send

Figure 9: An earlier 'phatic' SMS from Katriena to the same friend as in figure 8 
contacts, to 'cast out the net of social communication widely enough for one to hope to finally catch a big fish' (Horst and Miller 2006: 157).

In figure 8 we also see that Katriena expected answers to her messages and that she got irritated when people did not reply ('what is happening why don't you answer me'). Her best friend in Wesbank, who was also present during the cell phone course, never replied to Katriena's text messages, even after they both had learned how to compose and send them. Katriena always mentioned this to me when I saw her, and her friend's reluctance to reply was the object of several discussions between them. As mentioned above, phatic interaction creates expectations of reciprocation. Katriena clearly regarded her phatic exchanges as a valued form of communication one should not overlook or ignore. Just as one expects a greeting back when one greets a neighbour in the street, Katriena also expected an answer to her text messages. Messages lacking any form of meaningful information or content, only intended to greet and to 'link-up' with people in one's network, are real communicative gestures with certain intentions, implications and consequences. SMS messages can create new forms of intimacy and can form and deepen relationships, 'enhancing the ability to be communicatively present while being physically absent' (Wajcman et al. 2008: 648). Accordingly, when Katriena was away for a week, visiting her birthplace, she sent SMSs to be in constant contact with her son, her neighbour, her daughter and her best friends in Wesbank.

\section{Linda}

During my fieldwork, Linda, a 25-yearold Afrikaans-speaking resident of Wesbank, was living together with her 3-year-old daughter, her mother, her brother, and her little sister. If tested, Linda would probably be diagnosed with a severe form of dysgraphia. Sitting bored at home, Linda did, however, spend most of her days and nights on MXit, chatting with friends from outside and inside the community. The moment that I met her she was just replacing her mother as a caretaker. After having dropped out of high school she had never been formally employed. Her friends had introduced her to MXit and were still assisting her with her reading and writing on the program. Since the first day she had been on MXit, she had been copying words and sentences with pen and paper from her chat partners and when asking for advice from her friends. Papers and notebooks in which Linda had taken 'textspeak'" notes-words, sentences, and expressions she might copy and use in the future-were scattered all over the house. This 'corpus' of copied material was the main instrument by means of which she was capable of sustaining and extending her (virtual and offline) network. When Linda engaged in MXit interactions, she copied standard 'passe partout' phrases and expressions. These writing resources formed a tightly closed package of copied and memorized words as she could hardly improvise and innovate in her writing, she asked standard questions such as 'wat maak jy' ('what are you doing'), 'hoe gaan dit' ('how are you?') and was able to reply to such predictable and phatic questions by means of routine answers ('ek is bored' - 'I am bored' - 'ek is by die werk' - 'I'm at work'). This way she could keep conversations going for a while; through the use of these phatic expressions, she managed to appear as a competent user of MXit and this apparently satisfied the requirements of interaction and her wish to be in touch with her social network (Blommaert and Velghe 2012). 
Inthetranscribedinstantchatmessages between Linda and me (see conversation 1 and 2 below), phatic expressions are omnipresent. Both conversations are predominantly in Afrikaans textspeak. The 'standard' Afrikaans spelling is given between brackets in the third column and the English translation can be found in the last column on the right. In the first conversation, one can see that the whole exchange did not transcend mere phatic exchanges ('how are you', 'I am at home', 'what are you doing now', etc.). Linda's sentences were all very short and she was clearly taking fewer turns in the conversation than me. When I tended to exceed the phatic content by using longer sentences or asking a lot of questions, she simply did not answer me. When I asked her how long she still had to work, she kept quiet until I asked her a new question nine minutes later (see: 'I hope everything is ok at your job'), probably because she did not understand my first two questions ('For how many days?' and 'For how many nights?').

During the second conversation, the limitations of Linda's literacy repertoire became very clear. I opened the conversation with two general phatic questions ('alles goed?' en 'wmj?') and I receive a general, routine answer ('I'm just sitting here watching tv and you?'). In the two next turns, I answered Linda's 'and you?' question by providing information about my whereabouts and

\section{Conversation 1:}

\begin{tabular}{|c|c|c|c|}
\hline $17: 50$ & Me: & Linda: Dag Linda hoe gaan dit? & Hello Linda how are you \\
\hline $17: 50$ & Linda: & leka en mt jo (lekker en met jou) & Good and you \\
\hline $17: 52$ & Me: & $\begin{array}{l}\text { Joh ek kan die kleur van jou letters baie } \\
\text { moeilik lees! }\end{array}$ & $\begin{array}{l}\text { Joh, I can hardly read the colour of your } \\
\text { letters! }\end{array}$ \\
\hline $17: 53$ & Linda: & ohk & $\mathrm{Ok}$ \\
\hline $17: 54$ & Me: & Mr alles gan goed & But everything's ok \\
\hline $17: 54$ & Me: & Ek is by die huis & I'm at home \\
\hline $17: 56$ & Linda: & $\mathrm{O}$ & $\mathrm{O}$ \\
\hline $17: 57$ & Me: & Wat het jy gemaak vandag? & What did you do today? \\
\hline $17: 57$ & Linda: & Wmjdn (wat maak jy dan nou) & What are you doing now? \\
\hline $17: 58$ & Me: & Ek werk op my computer & I'm working on my computer \\
\hline $17: 58$ & Linda: & by die werk nu & At work right \\
\hline $17: 58$ & Me: & Ek moet $\mathrm{n}$ article skryf & I have to write an article \\
\hline $17: 58$ & Me: & Is jy by die werk? & Are you at your work? \\
\hline $17: 59$ & Linda: & $\mathrm{k}$ & Ok \\
\hline $17: 59$ & Linda: & jip & Yes \\
\hline $18: 00$ & Me: & Vir hoeveel dae? & For how many days? \\
\hline $18: 00$ & Me: & Vir hoeveel nagte? & For how many nights? \\
\hline $18: 09$ & Me: & Ek hoop alles gaan goed met die werk & I hope everything is ok at your job \\
\hline 18:09 & Linda: & ja baie goed & Yes, very good \\
\hline $18: 10$ & Me: & Dit is goed om te werk & It is good to work \\
\hline $18: 10$ & Me: & Wanneer gaan jy huis toe? & When are you going home? \\
\hline $18: 10$ & Me: & Mre (môre) & Tomorrow \\
\hline
\end{tabular}




\section{Conversation 2:}

\begin{tabular}{|c|c|c|c|}
\hline $10: 47$ & Me: & Alles goed? & Everything alright? \\
\hline 10:50 & Me: & Wmj? (wat maak jy) & What are you doing? \\
\hline 10:49 & Linda: & Siu ma hier kijk tv nj (... en jy) & Just sitting here watching tv and you \\
\hline 10:51 & Me: & Ek is by die huis & I'm at home \\
\hline 10:51 & Me: & Ek lees vir die universiteit & I'm reading for university \\
\hline 10:52 & Me: & Wat is siu? & What is siu? \\
\hline 10:52 & Linda: & ohk & Ohk \\
\hline 10:52 & Linda: & wt? & What? \\
\hline 10:53 & Me: & $\begin{array}{l}\text { jy skryf siu mar ek weetnie wat dat } \\
\text { beteken'ie }\end{array}$ & $\begin{array}{l}\text { You write siu but I don't know what that } \\
\text { means }\end{array}$ \\
\hline 10:54 & Linda: & ok & Ok \\
\hline 10:54 & Linda: & wat gaan jy vandag mk & What are you going to do today \\
\hline 10:55 & Me: & wat is csclol in jou status & What is csclol in your status \\
\hline 10:55 & Me: & Ek bly by die huis om te werk & I stay at home to work \\
\hline 10:56 & Linda: & $\mathrm{x}$ weetie & I don't know \\
\hline 10:57 & Linda: & ohk & ok \\
\hline 10:57 & Me: & jy skryf dit in jou status & You write this in your status \\
\hline 10:59 & Linda: & ja & yes \\
\hline 10:59 & Me: & En wat beteken dit? Ek is nuuskierig & And what does that mean? I'm curious \\
\hline 11:00 & & "Linda is now busy" & Status message \\
\hline 11:02 & Linda: & g2g & Got to go \\
\hline 11:02 & & "Linda is now offline" & Status message \\
\hline
\end{tabular}

activities ('I'm at home' and 'I'm reading for university') to then, in the third turn, inquire about the meaning of 'siu'. Linda first answers with 'what?' after which I repeat my inquiry ('You write siu but I don't know what that means') but I only get an 'ohk' as an answer. Linda tried to bring the conversation back to a mere phatic exchange by immediately posting another routine, standard question ('what are you going to do today?'). I gave a routine answer to that question ('I stay at home to work'), but before I did that I asked her another informational question about the status line she had written in her profile ("what is csclol in your status?'). On MXit like on other social media platforms, members can enter a status-often a slogan or a motto-in their profile. Linda was changing her profile status almost daily, another sign of her desire to be perceived as a competent user. Probably a copy or a transcription from a dictation by one of her friends, Linda's status that day read: 'WU RUN THE WORLD GALZ ... WU FOK THE GALZ BOYS ... LMJ NW HOE NOW::op=csclol=@' ('who runs the world girls ... who fuck the girls boys ...'). Linda probably accurately copied part of the phrase into her status, but the end of the status was very unclear and looked rather like a random compilation of signs. As an ethnographer in the field I had been deeply immersed in informal learning practices of textspeak 
(see Velghe 2011) and was thus used to constantly inquiring into the meaning of what I received and perceived. By asking Linda what csclol meant, I forced her again to transcend the mere phatic exchange of routine, standard questions and answers. Linda first answered with 'I don't know' after which I told her that she however had written csclol in her status, implying that she should know what she had written. She answered with a 'yes' two minutes afterwards (a marked pause in an instant messaging environment) after which I again clarified my question ('what does it mean? I am curious'). Suddenly after that, however, the status message 'Linda is now busy' appeared on my screen, followed by Linda writing a standardized 'g2g' (textspeak for 'got to go') and effectively going offline (Blommaert and Velghe 2012).

In the two transcribed instant messaging conversations, it is clear that Linda was quite fluent in asking and answering routine, phatic questions (How are you? What are you doing? I am at work. I am watching television and you?, etc.). She seemed, however, to quickly reach her literacy limit when different questions, requiring generative, non-routine answers and exceeding mere phatic content, were being asked. In order to avoid being exposed as a dysgraphic or 'illiterate' person, my insistence on an explanation forced her to withdraw from our conversation (Blommaert and Velghe 2012).

Sitting bored at home, MXit chatting was one of the most important (social) activities in Linda's life. Through a limited set of interactional practices, Linda managed somehow to be seen as a competent MXit chatter by her network of MXit friends. The reason that she managed to be seen as a 'fully competent' member was because her messages were less seen as linguistic objects than as indexical ones, not as carriers of intricate denotational meanings but as phatic messages that supported Linda's role as a group member and defined her relations with her peers as agreeable and friendly (Blommaert and Velghe 2012: 20). Linda's use of textspeak was not primarily a use of 'language', it was a deployment of voice-of a sign system that opened channels of peer-group communication and conviviality, and established and confirmed Linda's place in her network of friends (Blommaert and Velghe 2012: 20). In other words, Linda did not invest so much time and effort in the learning and writing of these signs because they enabled her to express denotational meaning (we have seen the limits of her generative writing and reading skills), but because they were a crucial and essential social instrument for her; one of the few very valuable instruments she possessed to make herself recognizable and respected as a human being. Through the support of her friends and her amassed 'corpus of textspeak', Linda was able to apply the mere phatic exchanges in order to be 'out there', be in constant social contact with others from within the four walls of her small house, and build a sense of conviviality while almost 'saying nothing'. Because of her disability, phatic exchanges for Linda, were of vital importance since they were the only possible way to be in touch and connect with the world around her.

\section{DISCUSSION AND CONGLUSION}

Most of what has been discussed here is in line with the research by Horst and Miller (2005, 2006) on low-income families in Jamaica. More focussed on calling 
practices with the mobile phone, Horst and Miller have introduced the term link$u p$ to refer to the extensive networking practices of very short phone calls to a lot of different contacts in people's networks (Horst and Miller 2006). Those link-up calls often have merely phatic content or aims, consisting of questions such as 'Hi how is everything?' or 'wa gwaan?' (Jamaican Creole for 'what is going on?') and replies such as 'Oh, I'm ok, I'm just enjoying summer' (Horst and Miller 2006: 96). According to them, link-up is characterised by very short calls made every couple of weeks to a high number of contacts, in order to keep the contact lists constantly active (Horst and Miller 2005: 760). According to the main cell phone carrier in Jamaica, the average mobile phone call there lasts only 19 seconds (Horst and Miller 2006: 96). The most important aspect of those phone calls is not the content of the conversations but 'their use to maintain connections over time', all of these interactions 'representing potential connections that were usually operationalized only at the time of a specific need' (Horst and Miller 2005: 760). The link-up calls are 'extensively used for economic development and coping but it is not particular to times of need' (Horst and Miller 2006: 96). Horst and Miller see these link-up calls as a consequence of the characteristic of Jamaican communication, in which the desire to forge links and to be in touch about 'nothing in particular' becomes important in its own right (Horst and Miller 2006: 96). The predominantly phatic link-up calls observed by Horst and Miller in low-income settings in rural and urban Jamaica tended to create safety networks that eventually could be activated in relation to monetary, emotional, practical or sexual needs. The functions of the Jamaican link-up phenomenon are thus similar to what Lisa was achieving by popping in on a regular basis at friends' and neighbours' houses in Wesbank, or Katriena using her text messages to set doors ajar to sociability with people in her (mobile phone) network, and Linda having routine conversations on MXit.

According to Horst and Miller (2006: 97), link-up has become the foundation to communication in Jamaica as well the basis of networking: it can be built upon 'to create relationships, realize projects and gain support, whether emotionally, practically or financially'. Similarly to the case of Wesbank residents discussed here, Horst and Miller stated that:

What the poorest individuals really lack is not so much food, but these critical social networks. The cell phone and its ability to record and recall upon 400 numbers, is therefore the ideal tool for a Jamaican trying to create the everchanging social networks that Jamaicans feel are ultimately more reliable than a company, employer or even a parent or spouse alone. This feature, perhaps more than any other, represents the critical economic impact of the cell phone in Jamaica. (Horst and Miller 2006: 111)

In other words, the difference between being destitute and not being destitute is, according to Miller (2006), a difference between having or not having friends or family that one can call upon in times of need. Horst and Miller found that in their rural research site, only $10 \%$ of the population were formally employed in reliable, regularly paid jobs and more than half the household incomes in their survey came from social networking rather than from any kind of labour or sales (Horst and Miller 2005: 761). Similarly, since so many Wesbank residents are (chronically) 
unemployed, they mainly survive thanks to the generous support coming from family, boyfriends, husbands, fellow church members, friends and neighbours, small and temporary informal sector employment such as the ones that Lisa had been involved in, or by applying for social security benefits such as child care and disability grants, or pensions.

In his response to the claim that the uptake of mobile phones in the developing world would generate an increased GDP, a general increase of income for the poorest of the poor, and close the so-called digital divide between the developed and developing countries with regards to access to ICTs, Miller (2006) stated that the vast majority of low-income individuals in Jamaica-just like in Wesbank-did not use their phone for entrepreneurial activities or to obtain formal employment. The critical economic impact of the mobile phone in Jamaica — and in my view more generally in the underdeveloped or developing parts of the world-is not due to its ability to generate income or to 'make money' (Miller 2008) but to its ability to 'get money' or, in other words, to immediately ameliorate financial or emotional 'suffering' (Miller 2008) through connectedness and sociability. Used as a means to this kind of 'conviviality', the mobile phone should thus not be seen as a luxury item that places an even heavier burden on people's finances, but as a necessity that is vital to mere survival and as 'an effective instrument for assisting in lowlevel redistribution of money from those who have little to those who have least' (Horst and Miller 2006: 114). The more people one has in one's social network, the more shock-resistant one becomes and through social networking and conviviality, Wesbank residents realized the need for 'casting out their safety nets' (Horst and Miller 2006: 157). The exchange of phatic gestures, whether face-to-face or 'virtually', has a clear influence on our perception of others, and being known in the community as a friendly, caring and benevolent person proved to be extremely helpful in coping with harsh conditions of poverty, insecurity, boredom and loneliness in Wesbank. As a communication tool, the mobile phone has proven to be the perfect instrument for such phatic exchanges and thus, for extending and strengthening one's networks, making it possible to link-up through short phone calls, text messages, Facebook wall posts, chat messages or PCM messages (see also Bidwell et al. 2011 on rural communities in South Africa).

Vincent Miller (2008: 393) stated that current communicative practices on Facebook and other social networking sites 'are motivated less by having something in particular to say (i.e. communicating some kind of information), as it is by the obligation or encouragement to say "something" to maintain connections to audiences, to let one's network know that one is still "there". Text, chat or Facebook messages should thus not only be looked at as 'linguistic' objects (as carriers of denotational meanings), but as indexical objects that are meant to be used to 'socialize' with others. We should measure these phatic exchanges by the standards of the indexical order of conviviality, instead of by the standards of language only. Language and literacy are always the means to (obtain) voice ('to let one be heard and understood'). Using phatic exchanges is a deployment of voice-of a sign system that opens channels of communication and conviviality and that establishes human beings as members of communities and networks that in places like Wesbank can be vital for survival. For people in Wesbank, making sure that people know that you are still 'there' can have an influence on whether one will have bread on the table at the end of the day or not. The exchange of phatic gestures is 
not a new phenomenon and neither is the exchange of phatic gestures as a coping strategy in impoverished communities like Wesbank. The high uptake of the mobile phone has given the people just another means through which they can now 'cast out their nets' and create extended networks through extensive rather than intensive calling and texting. It has given the people a new instrument for communication and networking that can be used from within the safe environment of the home, spanning forever increasing circles of acquaintances and distances.

\section{ENDNOTES}

1 In this article I call Wesbank a 'community' instead of a 'township', 'settlement', or 'area'. Residents of the area themselves refer to Wesbank as 'a community', both in the physical sense (community as a place or an area) but also in the social sense (community as a group of people).

2 The term 'coloured' remains problematic, as it formed part of the segregation policy of the apartheid government to clearly define and divide different sections of the South African population. On the other hand it is a firmly entrenched term and the racial categorizing terminology still persists in the appellation of people of mixed race ('coloureds') and 'blacks' and 'whites', and is still used by the South African population itself. In this article inverted commas are used to indicate this dilemma.

3 Exchange rate on May 26, 2015.

4 Here again, more recent statistics for the area are, unfortunately, not available.

5 Ward 019 includes the areas of Blue Downs CBD, Brentwood Park, Camelot, Delro Village, Driftsands, Gersham, Hagley, Highbury, Highbury Park, Highgate, Hindle Park, Rotterdam, Silversands, Stellendale, Sunbird Park, Wembley Park, and Wesbank. Most of them are socio-economically and demographically similar to Wesbank.
6 MXit can be accessed on mobile phones and is comparable to computer-based instant messaging programs such as MSN Messenger. MXit users can chat either in chat rooms (often centred around specific themes, geographical locations or age groups) or one-to-one with contacts one has to invite and accept (Chigona and Chigona 2008). The fast growth and popularity of MXit may partly be attributed to its cheap costs; a MXit message costs 2 South African Rand cents compared to 70 cents for an SMS (Chigona and Chigona 2008).

7 A PCM message or 'Please call me' message is a free service offered by the cell phone providers; it allows sending free text messages to any other telephone number in cases of emergency when one runs out of airtime with a request to call back. Those free messages - a daily limited amount of them - read 'please call me' and feature the number requesting the call-back, followed by an advertisement. Nowadays, one can add a short personal message of ten characters to these PCMs and personalise the telephone number by adding one's own name or nickname. For many middleaged 'subliterate' women in Wesbank, a PCM is next to calling and receiving calls the only thing they (can) use their handsets for.

8 'Textspeak' is the name given to the global medialect or the mobile texting codes, characterized by abbreviations, acronyms, initialisms, non-standard spellings and emoticons.

\section{REFERENGES}

Achmat, Fowzia and Ashley Losch. 2002. Wesbank: Power is the name of the game ... power is the name of the problem. In Ismael Davids (ed). Good Governance and Community Participation: Case Studies from the Western Cape. Cape Town: Foundation for Contemporary Research. Unpublished.

Bidwell, Nicola J., Mounia Lamas, Gary Marsden, Bongiwe Dlutu, Matt Jones, 
Bill Tucker, Elina Vartiainen, Iraklis Klampanos, and Simon Robinson. 2011. Please call ME.N.U.4EVER: Callback and social media sharing in rural Africa. Proceedings $10^{\text {th }}$ International Workshop in Internalisation of Products and System. Malaysia. 117-138.

Blommaert, Jan. 2012. Complexity, accents and conviviality: Concluding comments. AAAL 2012. Panel on 'Constructing identities in transnational spaces'. Tilburg Papers in Culture Studies, Paper 26. <http://www.tilburguniversity.edu/ research/institutes-and-research-groups/ babylon/tpcs/>

Blommaert, Jan and Fie Velghe. 2012. Learning a supervernacular: Textspeak in a South African township. In Adrian Blackledge and Angela Creese (eds). Heteroglossia as Practice and Pedagogy. New York: Springer. 137-154.

Blommaert, Jan, Nathalie Muyllaert, Marieke Huysmans and Charlyn Dyers. 2005. Peripheral normativity: Literacy and the production of locality in a South African township school. Linguistics in Education: An International Research Journal 16 (4): 378-403.

Depypere, Hannelore and Fie Velghe. 2005. Passed and past in the present: The persistence of history in Wesbank, a post-apartheid township in South Africa. University of Gent. Unpublished MA Thesis.

Dyers, Charlyn. 2008. Language shift or maintenance? Factors determining the use of Afrikaans among some township youth in South Africa. Stellenbosch Papers in Linguistics 38: 49-72.

Chigona, Agnes and Wallace Chigona. 2008. Mixt it up in the media: Media discourse analysis on a mobile instant messaging system. The Southern African Journal of Information and Communication 9: 42-57.

City of Cape Town. 2013. 2011 CensusWard 019. <https://www.capetown.gov. za/en/stats/Documents/2011\%20Census/ Wards/2011_Census_CT_Ward_019_
Profile.pdf $>$

Horst, A. Heather and Daniel Miller. 2005. From kinship to link-up. Cell phones and social networking in Jamaica. Current Anthropology 46 (5): 755-778.

Horst, A. Heather and Daniel Miller. 2006. The Cell Phone: An Anthropology of Communication. Oxford, New York: Berg Publishers.

Horstmanshof, Louise and Mary R. Power. 2005. Mobile phones, SMS, and relationships: Issues of access, control, and privacy. Australian Journal of Communication 32 (1): 33-52.

Lacohée, Hazel, Nina Wakeford and Ian Pearson. 2003. A social history of the mobile telephone with a view of its future. BT Technology Journal 21 (3): 203-211.

Licoppe, Christian. 2004. 'Connected' presence: The emergence of a new repertoire for managing social relationships in a changing communication technoscape. Environment and Planning D: Society and Space 22: 135-156.

Malinowski, Bronislaw. 1923. Supplement 1: The problem of meaning in primitive languages. In Charles K. Ogden and Ivor A. Richards (eds). The Meaning of Meaning. London: Routledge \& Keegan Paul. 296-336.

Miller, Vincent. 2008. New media, networking and phatic culture. Convergence: The International Journal of Research into New Media Technologies 14 (4): 387-400.

Miller, Daniel. 2006. The unpredictable mobile phone. BT Technology Journal 24 (3): 41-48.

Velghe, Fie. 2014. 'This Is Almost Like Writing'. Mobile Phones, Learning and Literacy in a $100 \%$ South African Township. Tilburg University. Unpublished $\mathrm{PhD}$ thesis.

Velghe, Fie. 2011. Lessons in textspeak from Sexy Chick: Supervernacular literacy in South African instant and text messaging. In Kasper Juffermans, Yonas Mesfun Asfaha, and Ashraf Abdelhay 
(eds). African Literacies: Ideologies, Texts, Education. Newcastle upon Tyne: Cambridge Scholars Publishing. 61-85.

Vetere, Frank, Steve Howard and Martin R. Gibbs. 2005. Phatic technologies: Sustaining sociability through ubiquitous computing. Workshop Paper, Uniquitous Society Workshop. ACM CHI 2005, Portland, Oregon, 2-7 April 2005. <https://www.vs.inf.ethz.ch/events/ ubisoc2005/UbiSoc\%202005\%20 submissions/12-Vetere-Frank.pdf>
Wajcman, Judy, Michael Bittman and Judith E. Brown. 2008. Families without borders: Mobile phones, connectedness and home-work divisions. Sociology 42 (4): 635-652.

Zainudeen, Ayesha, Rohan Samarajiva and Ayoma Abeysuriya. 2006. Telecom use on a shoestring: Strategic use of telecom services by the financially constrained in South Asia. WDR Dialogue Theme $3^{\text {rd }}$ Cycle Discussion Paper, WBR0604, Version 2.0. $<$ http://ssrn.com/abstract $=1554747>$ 